jogon, továbbá a székely jog nökre vonatkozó kedvezményein alapult. A székely gyakorlat arra inspirálta az erdélyi asszonyokat, hogy leánynevüket megtartsák, azt önállóan vagy férjük nevével együtt használják.

\title{
Jegyzetek
}

A nemi gyámságot az 1874.évi XXIII. tc. törölte e

1840.évi XV. tc.

Szt. István II. törvénykönyve 29. fejezet, Szt. László II. tvk. 12 fej. és III. tvk. 6. fej. , Kálmán I. tvk. 56. fej Jancsó, Fodor, Szlemenics, Tóth, Katona, Kolozsváry stb. vö. Máday im. 37. o.

1723. évi CXI. tc.

Vö. 1545.évi XXI. tcx.

A jogtörténészek szerint a magyaroknál a hitbér a leány vételárából fejlődött ki - hasonlóan Európa más országainak jogfejlődéséhez - ahogy, a jegyajándék és a jegygyűrủ pedig a vásár megkötésekor fizetett „felpénzbỏl”(ma foglaló hasonlítható hozzá) alakult ki. Máday im. 85-90 o.

A Tripartitum 93. cikkelyének 4. §.-a felsorolja az egyes rendek hitbérének fix összegeit, főnemeseké 100 márka, köznemeseké és polgároké 50-50 márka. A 6.-8. \$-ból azt is megtudhatjuk, hogy 100 márka akkor egy kőből épült vár értékének, 50 márka pedig egy két tornyú templom értékének felel meg.

A magyar házassági vagyonjog a közszerzeményi rendszernek felel meg, s mint ilyen a nöknek kedvezö vagyonjogi rendszerek csoportjába tartozik. A különbözỏ rendszerek három jogi alapelvre - vagyonközössé kezelési közösség vagyon elkülönítés- és ezek különböző kombinációira vezethetök vissza. Máday im.66-71 kezer

o.

A nemesekre egyetlen esetben vonatkozott a közszerzemény, amikor a nemes embernek „feleségével való házassága alatt gyüjtött vagy vett ménes lovai ötvenen alul vannak egyenlően fognak köztük elosztatni..,” Werbőczy I. 101.c.

Az 1.§. ideiglenesen fenntartja azon nők választójogát, akik azt addig is gyakorolták.

Bónis György Cserei Farkashoz hasonlóan mind a nővér, mind a lány utódok fiúlányságát fogadja el, szemben Vargyasi Szolga Jánossal, aki csak a nővér fiúlányságára következtet. Vö. : Bónis im. 75.-86. o., Szolga im. 238, 245, o.

Vö:: 1674-ben Apor Ilona fuúlány törvényes gyermekei Apor István, László és Mihály Bónis im. 88. o

\section{Felhasznált irodalom}

Bónis György: Magyar jog-székely jog, Kolozsvár 1942. Ferenc József Tudományegyetem

Cserei Farkas: A magyar és székely asszonyok törvénye, Kolozsvár 1800.

Csíky Kálmán: A magyar nők jogai, Budapest 1894.

Gáspár Gabriella: A polgári nyilvánosság kezdetei Magyarországon, Bp. Agroinform 2002

Gáspár Gabriella: Die Stelle der Zeitschrift „Erdélyi Múzeum”(1814-1818) in unserer Wissenschaftsgeschichte In.: Specimina Nova, JPTE Történelem Tanszékének Évkönyve, Pécs, 1989 29-46 p.

Fábry Anna: Író nők vagy írónők? A női dilettantizmus és professzionalizmus kérdése a 19. századi magyar irodalomban $=$ Rubicon 2001/6. 25-29 o.

Fügedi Erik: Az Elefánthyak, Bp. 1992. Magvetô kiadó

Kazinczy Ferenc: Sophie, Bp.1984. Szépirodalmi kiadó

Kolozsváry Bálint: A közszerzemény biztosítása, Budapest, 1899.

Kempelen Béla: Magyar nemes családok 10 k.+ pótkötet, Bp. 1911-1932. Grill k.

Máday Andor: A magyar nö jogai a múltban és jelenben, Atheneum irod. és nyomdai Rt. 1913.

Nagy Irán: Magyarország családai czímerekkel és nemzékrendi táblákkal 1-12 k.+ pótkötet, Pest 1857-1868. Freibeisz István és Táth Mór $k$.

Péter Katalin: Nők önállósága, férfiak önállósága a társadalomban= Rubicon 2001/6. 20-24 o.

Székely (killényi ) Mihály: A nemes székely nemzetnek constitutiói, privilégiumai és a jószág leszállását tárgyazó nénely törvényes ítéletei, több hiteles leveles-tárakból egybeszedve, Pest 1818 . Trattner $k$.

Szolga (vargyasi) János: Székely jogi ötven kérdések s 102 feleletek, Marosvásárhely, 1844. Ref.koll.

Takáts Sándor: Régi magyar nagyasszonyok, Szépirodalmi könyvkiadó Bp.1982

Tárkány Szűcs Ernő: Mártély népi jogélete, Kolozsvár 1944. Kolozsvári Egyetem Jogtörténeti szeminárium

Tárkány Szücs Ernő: Magyar jogi népszokások, Bp. 1980. Gondolat k.

Tóth Zoltán: A rendi norma és a „,keresztyén polgáriasodás” = Századvég 1991. 2-3. sz. 75-130 o. 
A nők társadalmi helyzetének változása elsősorban három szférában, a munkavégzésben, oktatásban, és a hatalomban történő elmozdulásokból következett. ${ }^{3} \mathrm{Az}$ ideológia és a gazdaság munkaerő-szükségletének kényszerítő ereje együttesen játszott szerepet a női foglalkoztatottság növelésében. A modernizációs folyamatban az extenzív gazdasági fejlesztés keretén belül a kitűzött gazdaságpolitikai célok csak pótlólagos munkaerő bevonással voltak megvalósíthatók, ezért a Magyar Dolgozók Pártja (továbbiakban MDP) nőpolitikájában a nők munkaerő-tartalékként játszottak fontos szerepet. A munkaerő nők köréből történő utánpótlására annál is inkább szükség volt, mivel az ipari munka, mint domináns megélhetési forrás nem a kommunista iparositással vette idehaza kezdetét, hanem csak folytatódott a nagyjából a húszas években megindult tendencia. ${ }^{4}$ Erre az időszakra viszont a férfi munkaerőtartalékok már kimerültek, ezért csak a nők jöhettek igazán számításba. A megnövekedett keresletet fokozta, hogy szovjet mintára nálunk is „... tipikus XIX. századi fejlödési modell szerint alakulnak a népesség gazdaságszerkezeti viszonyai.” (Gyáni 1995: 555) Az ideológiai és gazdasági tényezők mellett nyilvánvaló, hogy a gyors változások nem annyira a magyar történelem és társadalom belső folyamataiból, hanem sokkal inkább a szovjet vezetés által kierőszakolt szocialista fordulat következményeként jöttek létre.

A célok megvalósításához számos elỏfeltétel megteremtésére volt szükség. Ezek közül az egyik a nők politikai és állampolgári megítélésének a férfiakéval azonos jogi alapokra kerülése, ami megszüntette a nemek közt meglévő jogegyenlőtlenséget.

\section{A politikai és állampolgári jogok változásai}

Míg a politikai és gazdasági változások egyszerre gyakoroltak pozitív és negatív hatást a nők helyzetére, addig a nők jogi helyzetének változásában egymásra épülő pozitív folyamatok követhetők nyomon. A nők politikai és állampolgári jogainak általánossá válása - megvalósulásuk körülményeitől függetlenül - 1945-től kezdődően néhány tényezőt leszámítva rövid idő alatt megteremtette annak lehetőségét, hogy a nők a társadalmi élet különböző területein a férfiakéval azonos jogokat élvezhessenek. Igaz, a jogszabályok nem szüntették meg automatikusan a mindennapok egyenlőtlenségeit, megalkotásuk és elfogadásuk főleg a megelőző történeti időszakokhoz viszonyítva vált kiemelkedő fontosságúvá, és elengedhetetlen feltételévé a nemek jogegyenlőségének.

A választójogi törvény alapján már 1945-ben biztosították, hogy a nők a férfiakkal azonos módon gyakorolhassák állampolgári jogaikat. ${ }^{5}$ Ettől kezdve már nem a nők általános választójogának a megszerzéséről folyt a politikai vita, nem azt kellett tehát bizonyítani, hogy a nő is alkalmas a politikai jogok birtoklására - ami a megelőző időszakok választójogi vitáiban pro és kontra érvként központi helyet foglalt el -, haaz elsô választásokon elszenvedett vereségét fỏleg a nöknek köszönhette, ezért az 1947-es kampányban kiemelt jelentősége volt a feléjük irányuló propagandának. Rákosi az Angyalföldön tartott nagygyülésen az MKP programja mellett agitálva kijelentette, "Túlzás nélkül el lehet mondani, hogy népi demokráciánk erejét, mint a meleget a hömérön, számszerüen le lehet olvasni arról a szerepröl, melyet benne a nök visznek." (Rákosi 1997: 731). Programbeszéde Marxnak a nőkérdéssel kapcsolatos állásfoglalásából, valamint a nemek egyenlőségére vonatkozó nézeteiből vezethető le: „Egy történelmi korszak változása mindig meghatározható a nők szabadság felé haladásának arányából, mert itt a nőnek a férfihoz, a gyengének az erőshöz való viszonyában jelenik meg a legnyilvánvalóbban az emberi természetnek a durvaság feletti győzelme. A nők emancipációjának foka az általános emancipáció természetes fokmérője.” A két idézet alapján jól érzékelhető a marxi gondolatok és a marxista ideológia közötti különbség, és az ez utóbbi alapján szerveződő pártok nőpolitikájának leegyszerüsítő, vulgáris jellege.

Rákosi a választási eredmények értékelésénél a párt nőpolitikájának sikereként tüntette fel, hogy a 402 képviselő között 71 nő került be a parlamentbe. Mivel a képviselőnőkből 41 ipari munkás, 21 pedig a mezőgazdaságban dolgozó parasztasszony vagy lány volt, ebből azt a következtetést vonta le, hogy „... az egyenjogúsítás különösen a dolgozó nóket érinti.” (Rákosi 1951: 57). Az 1953. évi II. Törvényben a választásra jogosultak korhatárát 20 évről 18 évre szállították le, ez a változtatás mindkét nemet érintve tovább növelte a női szavazók számát.

A politikai jogok gyakorlásának lehetőségét a választójog mellett a választhatóság, a politikai szerepvállalás garantálja. A női képviselők aránya 1945-ben 3,1\%, 1947-ben 17,2\%; az 1953-as választáson valamivel kevesebb, $11 \%$ (52 nő) került be a parlamentbe, ennek az utóbbinak azonban a parlamentáris demokrácia ellehetetlenülése miatt már nem volt sok jelentősége. ${ }^{8}$ Ez azért is sajnálatos, mivel ettől kezdve adódhatott volna igazán lehetőség arra, hogy a nők is megtanulják a politikusi szerepet, illetve, annak gyakorlásával, politizáló nőként elfogadtassák magukat a társadalmi nyilvánossággal.

A nemek jogegyenlőségének másik megnyilvánulása volt, hogy 1945. novemberétől a nőt is kinevezhették gyámnak vagy gondnoknak. Ez az intézkedés azt az 1877 óta fennálló jogtalanságot szüntette meg, mely szerint a nőket - a Tanácsköztársaság rövid időszakának a kivételével - jogilag gyámságra vagy gondnokságra alkalmatlan személynek nyilvánították.

A nők művelődéshez, pályaválasztáshoz és munkavállaláshoz fűződő jogát a férfiakéval azonos módon definiálták. A szabad művelődéshez való korlátlan hozzájutás lehetőségét az 1945. augusztus 18-án megjelent 6600/1945. ME számú rendelet biztosította, amely lehetővé tette végre a nők számára is az állam- és jogtudományi karokra való bejutást. Az 1946. október 21-én megjelent XXII. számú törvény - a hittudományi karok kivételével - valamennyi egyetem és főiskola kapuját megnyitotta a magyar nők előtt. (Tóth 1975: 25). Az 1948. évi XLIII. törvénnyel nemcsak az oktatásban, hanem a munkavégzésben is megteremtődött a férfiakkal azonos pályaválasztási, munkavállalási lehetőség. 
Az állampolgári jogok szabályozásai közül még egy, a nemek egyenlőségét elősegítő momentumot érdemes itt megemlíteni, annak ellenére, hogy ez a polgárok számbavételére irányult, ami nem tekinthető kifejezetten a szabadságjogok megnyilvánulásának. ${ }^{9}$ Véleményem szerint ugyanakkor a személyi igazolványok 1954-ben történt bevezetésének volt egy látens, hosszabb távon érvényesülő pozitív hatása is a nők számára, mégpedig azáltal, hogy ily módon ők is önálló (és persze nyilvántartásra kötelezett) személyekké váltak. A hangsúly itt az önállóságon és azon van, hogy 14. életévük betöltésekor a nők a férfiakhoz hasonlóan, személyi igazolványt kaptak. Ezekkel az intézkedésekkel megváltozott addigi társadalmi megítélésük. Az 1954-ig érvényben lévő gyakorlat szerint ugyanis a férjezett nőknél elegendő volt, ha nevüket és adataikat a férjről kiállított be- és kijelentőlap tartalmazta. A külön igazolvány személyiségi jogaik elismerését jelentette, és ettől kezdve a férjezett nők megszűntek a férj tartozékává válni. További pozitív jelentősége a személyi igazolványnak, hogy a nőknél is bevezették a 18. életévüket még be nem betöltött gyermekek adatait, ezzel jelezve, hogy szülőként is azonos jogok illetik meg őket.

A már említett jogszabályok az új családjogi törvénnyel együtt biztosították a nők számára a férfiakkal azonos jogokat. ${ }^{10}$ Jelentőségük abban áll, hogy az 1942-ben érvényben lévő jogi szabályozás szerint törvényileg biztosított pozitív diszkriminációt élveztek a férfiak „...bár elvileg a férfi és nő között a magánjogban nincs különbség, de a férfit mégis elöjogok illetik meg. Ö a család feje."11 Ez a családfői funkció magas társadalmi presztízst, jelentős előnyöket biztosított a férfiak számára. Az új családjogi törvény viszont megsemmisítette, eltüntette ezeket az előjogokat.

\section{Az új családjogi törvény}

Míg a jogszabályok megváltoztatásával megteremtett formális jogegyenlőség jól kontrollálható, addig a nemek közti egyenlőségnek a mindennapok gyakorlatában való érvényesüléséről - különösen a családi élet keretein belül - keveset tudhattunk meg az ötvenes évek dokumentumait elemezve. A tradicionális szerepek és az ezzekkel együtt járó alárendelt helyzet fennmaradására inkább csak a későbbi időszakok időmérleg vizsgálataiból következtethetünk. Ennek ellenére a családi együttélésre vonatkozó törvények módosítása, a megvalósulás feltételeinek a részletes szabályozása nemzetközi összehasonlításban is pozitívumként értékelhető, amely a magánélet területén is megtette az első lépéseket a nők házasságon belüli jogegyenlősége irányába.

A törvényalkotók a megváltozott gazdasági alap következményeként szükségesnek tartották a „házasság, a család, a gyámság szocialista jogintézményének felépítését."12 Az 1953. január 1-én életbe lépő Családjogi törvény (1952:IV) az alkotók szándéka szerint megfelelő jogi formát igyekezett biztosítani az új tartalomhoz, a cél pedig az volt, hogy megteremtsék a családtagok között az egyenlő elvárások elvét. Abból indultak ki, hogy a „szocialista házasság két szabad, és egyenlö ember kölcsönös vonzalmára alapított közösség," ezért a nők jogait úgy kell definiálni, hogy őket a há- zasság ideje alatt, a házasság felbontása esetén, valamint a gyermekelhelyezés tárgyában is a férjjel azonos jogok illessék meg.

A házastársaknak a házasélet ügyeiben egyenlő jogaik és kötelezettségeik vannak (23. §),

A házastársak kötelesek egymást kölcsönösen támogatni, egymáshoz hủségesnek lenni (24. §)

A házastársaknak a közös lakás helyét egymással egyetértve kell megválasztaniuk, bármelyik fél beleegyezésétől csak alapos indok esetén lehet eltekinteni (25. §). A törvény elfogadása előtti időszakban erre a férj volt egyedül jogosult.

A törvény a nő házasság utáni névhasználatát a feleség választására bízta, megszüntetve ezzel azt a megelőző joggyakorlatot, mely szerint a feleség a házasságkötés után csak az asszonynevét viselheti.

Ez utóbbinak, a név megválasztásának a szabadsága mellett jelentős, hosszabb távú társadalmi hatása is volt. Egyrészt megszüntette azt a jogilag alátámasztott gyakorlatot, amely azt fejezte ki, hogy a férjezett nő a férj tartozéka, annek mintegy a tulajdona. Másrészt a férj nevének a viselése, mint státusszimbólum sokat vesztett jelentőségéből, és ezzel mérsékelte azt a negatív társadalmi megítélést, amely a leánynéven szereplő nőkkel szemben bizonyos életkor felett ekkor még tapasztalható volt.

A törvény a házasság megkötésétől számítva vagyonközösséget deklarált akkor is, ha egyik vagy másik házastárs nem folytatott kereső tevékenységet. A háztartás költségeinek a közös fedezése, valamint a közös vagyonkezelés törvényi előírásai szintén a házasságon belüli egyenlő gazdasági viszonyok megteremtésének a jogi alapját alkották.

A szülői felügyelet együttes gyakorlásának a joga a nők családon belüli egyenjogúságának vált egyik alapvető tényezőjévé. A törvényalkotók arra törekedtek, hogy megszüntessenek a családon belül minden hatalmi hierarchiát - beleértve a generációk közöttieket is -, ezért a „szülői hatalom” fogalmát a „szülői felügyelet” fogalmára cserélték fel.

Mindezeken túl a családjogi törvény nemcsak a házasságon belüli egyenjogúság lehetőségeit, hanem a sikertelen együttélés felbontására vonatkozó jogokat is definiálta. A házasság felbontására vonatkozó paragrafusok szintén új szemléletet képviseltek a férfi és nő viszonyában, ezt példázza a vétkesség elvének az eltörlése is. ${ }^{13}$ A magyar jogalkotás ezzel megelőzte a fejlett polgári társadalmak vétkességet mellőző válási törvénykezését; például az Egyesült Államok 16 szövetségi államában 1971-ben, Franciaországban 1975ben megalkotott jogszabályok kodifikálták csupán a vétkesség eltörlését.

A jogegyenlőséget biztosító jogalkotási folyamat ellenére a politikai vezetés családhoz való viszonyát kettősség jellemezte. Annak ellenére, hogy törvénybe iktatták a nők családon belüli egyenjogúságát, illetve, hogy a férfiakkal azonos feltételek mellett kezdeményezhették a megromlott családi együttélés felbontását, a magánszférában nem történt alapvető változás. A családon belüli feladatok, a gyermekek ellátásának felelőssége továbbra is rájuk hárult. A rendszer egyik legszembetűnőbb ellentmondása éppen az, hogy a nemek egyenlőségét hirdető ideológia a társadalmi valóságban 
nem jelentett mást, mint a nőknek a nem tradicionális foglalkozások végzéséhez való jogát, ami a változatlan megterhelést jelentő családi feladatokkal együtt a társadalmi gyakorlatban közel sem eredményezhetett a férfiakéhoz hasonló lehetőségeket.

\section{Lehetőség és a valóság}

Az egyenlőségeszme csorbulása mind a munka, mind a magánélet világában tapasztalható volt. Miközben a nők aránya egyes foglalkozásokban folyamatosan emelkedett, ez tulajdonképpen a férfiak munkaerőpiaci esélyeit befolyásolta kedvezően. Különösen jellemző ez a szellemi foglalkozásokban. „A nők aktivitásának növekedése kedvezöen hatott a férfiak helyzetére, olyan értelemben, hogy lehetövé tette nagyobb fokú beáramlásukat a magasabb képzettséget igénylö és jobban fizetett foglalkozásokba." Andorka Rudolf (1982: 72) megállapítása a női foglalkoztatottság alakulásának általános törvényszerüségeire utal, amely a propaganda ellenére az ötvenes években is igaz volt: a nőknek akkor volt csak lehetőségük egyes foglalkozásokba tömegesen bekerülni, ha azt elértéktelenedő presztízs, alacsony jövedelem vagy mindkettő jellemezte.

Ez a tendencia érvényesült a döntéshozó és költségvetési intézményeknél, a tanácsrendszer kiépítése miatt megnövekedett adminisztratív munkáknál. A különböző szinteken, mint például a központi és helyi költségvetési szerveknél, a férfi és női munkaerő számbeli eltérést mutatott. A magasabb presztízzsel rendelkező központi szerveknél, ahol a döntések megszülettek a férfiak, míg a fỏleg csak adminisztrációs feladatokat ellátó helyi szerveknél a nők voltak többségben.

7. A költségvetés központi és helyi szerveinél foglalkoztatott férfiak és nők aránya százalékban ${ }^{14}$

\begin{tabular}{|l|c|c|c|c|}
\hline ÉV & \multicolumn{2}{|c|}{ Központi szervek } & \multicolumn{2}{c|}{ Helyi szervek } \\
\hline & Férfi & Nő & Férfi & Nő \\
\hline $\mathbf{1 9 5 2}$ & 58,4 & 41,6 & 49,6 & 50,4 \\
\hline $\mathbf{1 9 5 3}$ & 58,1 & 41,9 & 46,0 & 54,0 \\
\hline $\mathbf{1 9 5 4}$ & 58,0 & 42,0 & 42,9 & 57,1 \\
\hline
\end{tabular}

Annak ellenére, hogy a központi szerveknél a foglalkoztatottak száma alig változott, mindvégig megmaradt a férfitöbblet. A helyi szerveknél azonban a számszerủ növekedéssel párhuzamosan fokozatos eltolódás figyelhető meg a női munkaerő irányába, amely az erőteljes centralizáció, a túlszabályozott irányítás következtében a megnövekedett adminisztrációs terheknek tulajdonítható. Mivel jól ismertek a centralizált tanácsi irányítórendszer döntéshozó és végrehajtó funkciói, nem lehet kétségünk afelől, hogy a munkaerő nemek szerinti, fent vázolt megoszlása egyúttal a férfiak és nők közötti hatalmi hierarchiát is visszatükrözte.

$\mathrm{Az}$ adminisztratív állomány feminizálódása, az egyes értelmiségi szakmák elnőiesedése ugyanakkor nem járt együtt a hatalmi pozíciók átstrukturálásával a ne- mek között. A nők száma az 1949 és 1960 közötti években fỏleg a pedagógusok körében nőtt, 57,8\%-ról 74,8\%-ra az általános iskolában, középfokon 46,3\%-ról 40,2\%-ra változott. (KSH Adatgyüjtemény: 1977: 14) A középfokú oktatásban a nők száma a közismereti tárgyaknál ugyancsak növekedett, ám a statisztikai adatokban a férfiak által oktatott szakmai tárgyak nagy számának köszönhetően ez nem követhető.

A korszak mobilitási vizsgálatainak adataiból megállapítható, hogy a munkahelyi jobb pozíció megszerzésében a nők hátrányosabb helyzetén még az előnyösebb szülöi háttér sem sokat javított. „Ellentétben férfi testvéreikkel, ahol a fö jellemzö az értelmiségi helyzet megtartása volt, náluk a mobilitás fóiránya a fiatalabb korosztályokig az egyszerü foglalkozásokba tartott. Azt mondhatnánk, hogy a felszabadulás elött a vezetök és értelmiségiek leányainak tipikus helyzete a 'háztartásbeli' állapot, a felszabadulás után viszont az egyszerü szellemi foglalkozás a leggyakoribb életút." (Andorka 1982: 149). A statisztikai adatokat elemezve nem igazán találtunk példát annak a nőpolitikának a megvalósulására, amit az MDP meghirdetett, és amire Rákosi visszaemlékezéseiben is utalt. „Ennek a politikának megvalósulásaképpen elkezdtük a nőket a legmagasabb közéleti polcokra helyezni. Csakhamar megjelentek az elsö nöi miniszterek, nöi föispánok, illetve megyei végrehajtó bizottsági elnökök, Újpest nöi polgármestert kapott stb.” (Rákosi 1997: 727). Az egyes kiemelt, „kirakat” jellegü eseteket leszámítva a nők és férfiak - különösen a fontosabb pozíciók tekintetében - különböző esélyekkel indultak. A nők hátránya éppen a politikai, gazdasági vagy társadalmi élet területén, a vezető posztok megszerzésénél volt a legnagyobb.

A nők aránya egyes vezetői munkakörökben, 1953-ból származó adatok szerin (Lengyel 1958: 769):

Államigazgatási vezető munkakörben

Helyi tanácsoknál vezető munkakörben

Vállalati igazgató

Kereskedelmi vállalatvezető és ügyvezetó

Gépállomásvezetố

$8,3 \%$

$16,3 \%$

$5,2 \%$

$9,4 \%$

$4,2 \%$

Annak ellenére, hogy a háború előtti korszakhoz viszonyitva a nők lehetőségei a társadalmi és gazdasági élet területén kibővültek, a férfiakhoz viszonyított relatív hátrányuk kevéssé változott. A magas döntési jogkörrel összekapcsolódó értelmiségi pályákon, a politikusok és a gazdasági- államigazgatási hierarchia káderei között nők nem találhatók. Mivel az egész rendszer működését a legszűkebb pártvezetés irányította, nyugodtan kijelenthetjük, hogy a nők az ötvenes években a politikai, gazdasági, vagy a kulturális élet területén nem kerültek döntési pozícióba. Állításunk főleg a funkcionáriusok hierarchiájában elhelyezkedő nőkre igaz.

A hatalmat megtestesítő és az operatív munkát végző pártvezetésben - Politikai Bizottság, Titkárság - nők nem vettek részt. Az MDP három kongresszusára megválasztott elnökségben a nők száma kilenc-tíz között változott. Az MDP I. kongresszusán megválasztott Központi Vezetőség 66 tagja között négy volt nő. A II. és III. kongresszuson a 71-71 KV tagból hat, illetve hét volt nő (Vida 1985: 53-66). Andics Erzsébet és Ratkó Anna mindhárom alkalommal bekerült a KV tagjai közé. 1948-ban Mónus Illésné és Szász Ferencné, mint volt baloldali szociáldemokraták képviselték 
még a nőket. A II. és III. kongresszus is beválasztotta a KV tagjai sorába Jóború Magdát, Vass Istvánnét, míg Benke Valéria 1954-ben lett tagja a KV-nak.

A pártkongresszusok küldöttei között sem érte el a nők aránya az egyharmadot, az elnökségébe még ennél is alacsonyabb számban - kevesebb, mint $20 \%$ - kerültek be. A legfelső pártvezetésnek a nők politikai tevékenységére vonatkozó attitűdjéről azonban az adatoknál sokkal többet árul el a nők kiválasztásának formális a módja. Sztahanovisták, nem tradicionális női munkát végző ifjúmunkások, traktorosok képviselték a nőket a fontos párteseményeken, reprezentálva az új nőideálokat.

A nők politikai tevékenységet főleg az egyetlen női szervezetben, a Magyar Nők Demokratikus Szövetségében ${ }^{15}$ (továbbiakban MNDSZ) folytathattak, feladatuk ,a párt eszméit és akaratát átvigyék a lakosságnak a szervezet jellege szerint 'megcélzott' rétegére”, „transzmissziós” (Kornai 1993: 72) feladatot látva el a párt és a tömegek között. A feladatnak igazából azok a nők tudtak megfelelni, akik minden cselekedetüket a párt vezetőségének elvárásai szerint, gondolkodás nélkül végrehajtották. A nők akkori- és későbbi politikai és társadalmi szerepeinek a megítélése szempontjából nyernek ezek a jelenségek mélyebb értelmet. Mivel a nőszervezet funkcionáriusainak műveltsége az átlagnál is alacsonyabb volt, napjainkig továbbélő negatív attitűd alakult ki a politikai szerepet vállaló nőkkel szemben. Ugyanakkor a hatalmi hierarchia alacsonyabb szintjein tevékenykedő nők munkáját nemcsak a képzettség hiánya, hanem a férfiakból álló felső pártvezetés negatív attitűdjei is nehezítették. Ennek oka között egyaránt megtalálható volt a tradicionális női szerepeket hangoztató közvélekedés, valamint a funkcióba történő kiválasztás miatt kialakult ellenszenv.

\section{A nők társadalmi esélyegyenlőségét gátló tényezők}

A társadalmi újratermelési folyamatban való részvétel a nők számára akkor válhatott volna az esélyegyenlőség alapjává, ha a családi feladatokhoz kapcsolódó munkákat intézményesítik, valamint a gyermekek gondozásának-nevelésének a terhéből az állam jelentős részt vállal magára. Ehhez a gyermekellátó intézmények olyan volumenű emelésére lett volna szükség, amelyek mind a mennyiség, mind a nevelés minőségének tekintetében kielégítik a családok elvárásait. A pártvezetés viszont a nők egyenjogúságát, esélyegyenlőségét a magántulajdon intézményének felszámolásával, a nők társadalmi munkavégzésbe való folyamatos bekapcsolásával automatikusan megvalósulónak vélte és mint minden más területen, itt is a szovjet mintát másolta. ${ }^{16}$

A bölcsődei férőhelyek száma - a folyamatos növekedés ellenére - az ötvenes évek elején csak a 0-3 éves gyermekek 3,2\%-ának befogadására volt elegendő. A Központi Statisztikai Hivatal 1953. októberi (EÜ: 7/1953) jelentése szerint az adott korosztálynak csak 2,6 százaléka volt bölcsődés, miközben a gyermekes nők 38\%-a dolgozott (KSH 1958/II.: 765). A budapestiek ezen a téren előnyöket élveztek a vidéken élőkhöz viszonyítva, mivel a fővárosban a gyermekek 10\%-ának tudtak elhelyezést biztosítani.
Még lassabban növekedett az óvodai férőhelyek száma, annak ellenére, hogy ennek az intézménynek történeti hagyományai is voltak (Szalai 1986: 199-201). A magyar óvodapedagógiának már a két világháború között elkötelezett irányítói akadtak nálunk, munkájuk pozitívumai a későbbi időkben is meghatározták az óvodai munka alapelveit. A bölcsődei helyek számának relatív emelkedéséhez viszonyítva -, ami 1949-től négy-, négy és félszeres volt - az óvodában elhelyezhető gyermekek száma csak másfélszeresére nőtt, és egyedül 1951-ben haladta meg a háború előtti szintet. ${ }^{17}$ Az ide felvehető gyermekek alig érték el az adott korosztály egynegyedét annak ellenére, hogy a szakemberek többségének a véleménye szerint ebben az életkorban már pozitív hatása van a közösségben történő nevelésnek.

A gyermekellátó intézményeknek a szükségletnél kisebb mértékủ fejlesztése megduplázta a dolgozó nők terheit (KSH 1958: 765), mivel ilyen feltételek mellett nehéz volt a munkát és a családi kötelezettségeket egyszerre jól ellátni. Természetes, hogy az ezzel kapcsolatos problémák sem tartoztak a társadalmi diskurzus körébe, sőt, a propaganda a valósággal ellentétes jelenségeket mutatott be.

A családon belüli konfliktusok a nők egyre nagyobb arányú kereső tevékeny sége, és a nőknek a háztartással és gyerekneveléssel kapcsolatos — jelentősen nem csökkenő - terhei között komoly feszültség volt. Ez több tekintetben kárára vált mind a családi, mind a munkahelyi feladatok teljesítésének. Lengyel László a női foglalkoztatottságot elemző tanulmányában a következő megállapításokat tette: ”...a nök ilyen nagyarányú bevonása az aktív keresök közé bizonyos mértékig túlzott volt, nem egy vonatkozásban - elsősorban az ifjúság családi nevelését illetöen - kedvezötlen következményekkel járt. A nök munkába állásának folyamata túlságosan gyors volt, s így már eleve sem lehetett minden oldalról, sem gazdasági, sem társadalmi vonatkozásban kellöen megalapozott. A bölcsödék, a napközi otthonok, a közétkeztetés (...) szükségesnél lényegesen kisebb mértékü fejlesztése, a háztartások alacsony színvonalú gépesitése nem vette le a dolgozó nö válláról a háztartási és gyermeknevelési gondokat.” (Lengyel 1958: 765).

Az 1945-ben kodifikált egyenlő munkavállalói jogok a megvalósulásukat segítő intézmények alacsony száma, vagy nem megfelelő funkcionálása miatt a társadalmi gyakorlatban nem érvényesülhettek. A házimunka és a keresőtevékenység összehangolását az is akadályozta, hogy a problémákat a nőknek egyedül kellett (volna) megoldaniuk, mivel a tradicionális férfiszerepek eközben alig változtak. A kettős teherviselés a női egyenlőség megvalósítását kizárólag a társadalmi munkamegosztásban való egyforma részvételre szűkítő ideológia szükségszerű következménye volt. Az ellentmondásokat tovább mélyítette, hogy a növekvő női munkavállalás ellenére a legfelső pártvezetőség maga is bizonytalan volt, egyrészt az általa hirdetett „,dolgozó nő” ideálját illetően, másrészt a megvalósítás folyamatának a tekintetében. „A munkához való jog és kötelesség szempontjából a társadalomvezetés a nöket mindvégig bizonyos értelemben kivételnek tekintette (...) a nök esetében a munkavállalás joga elvileg vagy a közfelfogásban sem vált soha kötelezettséggé." Ferge Zsuzsa (1982: 140) megállapításai az államszocialista társadalom egész időszakára érvényesek voltak. 


\section{Dolgozó nők - háziasszonyok}

A pártvezetés céljait a nők felé közvetítő nőszervezet, az MNDSZ agitációs tevékenysége egyrészt a munkahelyekre, másrészt a háziasszonyokra is kiterjedt. Ez utóbbi csoportnál kettős feladatot kellett ellátni, bevonni őket a munkába, illetve rávenn őket, hogy férjüket hatékonyabb munkára buzdítsák. ${ }^{18}$ Különös jelentősége volt ennek az agitációnak a bányászfeleségek között, akik a „bányászbecsület védelméért is harcoltak", és mint az ország legmegbecsültebb dolgozóinak házastársai, segíteni kellett a férjeket abban, hogy méltóak legyenek a Párt, Rákosi bizalmára. A háziasszonyok tehát akkor válhattak a társadalom hasznos tagjaivá, ha házastársukat még több munkára, a tervek teljesítésére, túlteljesítésére ösztönözték.

A háziasszonyokat megcélzó propagandából kiolvasható, hogy az államszocializmus család- és nőképe jelentősen különbözött a tradicionális magyar társadalom családszerkezetétől, a férj-feleség mindennapokban megnyilvánuló kapcsolatrendszerétől. Éppen ezért a más értékrendszer alapján működő pártállamnak ahhoz, hogy hosszú távon hatékonyan funkcionálhasson, el kellett fogadtatnia új ideáljait. Az új értékrendszer kialakításának folyamata jól nyomon követhető a társadalom számára fontos ünnepek átalakítására irányuló törekvésekben.

\section{Nőnap - Anyák napja}

Az új nőideált a Nemzetközi Nőnap jelentőségének a hangsúlyozásával, ezzel párhuzamosan az előző időszak nőideálját szimbolizáló Anyák Napja leértékelődéséve kívánták a társadalom felé közvetítetni. Míg a két világháború közti időszakban a nő legfontosabb hivatásának tartott feleség és anyaszerep jelentőségét az mutatta, hogy az Anyák Napja kötelező ünnep volt az iskolákban, addig az 1945 és 1955 között években a hivatalos ünneplést eltörölték. Intézményesítésére majd csak 1955. május 7-én került újra sor, ugyanakkor a nők legjelentősebb ünnepe továbbra is március 8 . maradt. Az ünnepség intézményesítésére azért volt szükség, mivel a tapasztalatok azt mutatták, hogy a „klérus igyekezett azt (mármint az anyák napját) a maga számára felhasználva" minden esztendőben megünnepelni, és ennek megakadályozása végett javasolták újra iskolai ünneppé nyilvánítását. (MOL 276. f. 89/358)

Az MDP KV Agitációs és Propaganda Osztálya a következő javaslatot készítette a Titkárság részére a Nemzetközi Nőnap megünneplésére „A Nemzetközi Nőnap elökészületeit fel kell használni arra, hogy fokozódjék a magyar nők aktivitása a gazdasági, politikai és kulturális élet minden területén, és ezáltal is növekedjék a nők társadalmi megbecsülése." ${ }^{\prime 9}$ Természetes, hogy emellett még a Szovjetunió, a párt és az MNDSZ munkájának a népszerüsítése is szerepelt a feladatok között. Az ünnepség fényét az is erősíthette, hogy javasolták: a Párt KV írjon levelet a magyar nőkhöz, melyet a sajtó, rádió ismertessen, és az ünnepségeken olvassák is fel. Az ünnepség nem más, mint a nép tisztelete az öntudatos, dolgos, harcos asszonyok, édesanyák, feleségek és lányaik iránt. „A magyar nök ezután is mindenütt ott lesznek, ahol a béke nagy ügyéért cselekedni kell." Ez pedig, a dokumentumok szerint, nem lehetett más, mint a munka frontja és más társadalmi tevékenységek. A Nőnap méltó megünneplése nem történhetett volna másként, mint a nők tömeges teljesítmény-felajánlásával, a haza gazdasági erejének növelésére irányuló még fokozottabb munkálkodásával

A feleség/anya szerepkörről a társadalmi munkamegosztásban tevékenykedô nőre történő áttérés a „csak családjáért,, dolgozó nő presztízsének a leértékelődésével járt együtt. Ezt a tendenciát erősítette továbbá, hogy a nőnap átvette az anyai szerepkör funkcióját is. „Az édesanyák magasztos feladatukhoz méltóan teljesitsék családi és szülői kötelességeiket, hogy gyermekeiket, dolgos, müvelt, hazájukat szeretö emberekké neveljék" (MOL 276. f. 89/163. ő. e. 409.) Az idézetből kiolvasható, hogy itt nem a családi intimitás megteremtése, hanem a társadalom nagy közösségéért végzett tevékenység vált az anyák alapvető feladatává.

1954-ben ugyan megrendezték az Anyák Megyei-, majd május 7-8-án az Anyák Országos Konferenciáját, az összejövetelek témája igen távol esett a világháború előtti anyák napi ünnepségekéitől, a tradicionális családokban betöltött anyai szerepkörtől, s helyette a szocialista közösségért dolgozó nő vált hangsúlyossá.

\section{Karácsony - Fenyőfa ünnep}

Egyes eseményekhez, személyekhez kapcsolódó ünnepek előtérbe kerülésének, vagy éppen eljelentéktelenítésüknek és megszüntetésüknek a konkrét tartalomtól elvonatkoztatott, tágabban vett ideológiai okai is voltak. Mivel „a karácsony 1945-óta harcot jelentett a demokratikus erök és a klérus között”, ennek az ünnepnek áttranszformálása „Fenyőfa ünneppé” egyidejüleg szolgálta az ünnep egyházi jellegének háttérbe szoritását és a nök kivonását a klérus hatása alól” (MOL 276. f. 89/163. ő. e. 58.) A Vallás és Közoktatásügyi Minisztérium 1950. november 28-án megfogalmazott levele szerin az ünnep új jelentést kapott, amely nem volt más, mint a békeharcra és a nemzetköz szolidaritásra történő mozgósítás. A nőnevelők feladatává tették az akció politika tartalmának állandó tudatosítását és ezzel a karácsonyi „előkészülésnek” az eddigitő eltérő módon való megszervezését. A szervezők még arra is vigyáztak, hogy ne legyen jelmezbál, mivel az esetleg az előző évek betlehemes játékaira emlékeztethetett volna. Az előkészületekre szánt rövid idő is azt a célt szolgálta, hogy a december 22-én, 23án és 24-én tartandó próbák megakadályozzák a gyermekeket, hogy felkereshessék a templomot, ezért a központilag előírt műsorokat csak december 19-én küldték ki a településekre. Ugyanilyen okokból tették kötelezővé a foglalkozásokon való részvételt 25-én és 26-án délelőtt a tanulók, délután pedig a szülők részére. 1952-ben, szovjet példa alapján, a karácsony másnapját törölték a hivatalos ünnepek sorából, helyette május 2-át fizetett munkaszüneti nappá nyilvánították. A karácsony, a családi körben eltöltött szeretet ünnepe egy napra szűkült le, és még ekkor is külön programokon kellett részt venniük a családtagoknak.

Tovább is sorolhatnánk az említett esetekhez hasonló példákat, amelyek az ötvenes években a megelőző társadalom jeles eseményeinek a megváltoztatására irá- 
még a nőket. A II. és III. kongresszus is beválasztotta a KV tagjai sorába Jóború Magdát, Vass Istvánnét, míg Benke Valéria 1954-ben lett tagja a KV-nak.

A pártkongresszusok küldöttei között sem érte el a nők aránya az egyharmadot, az elnökségébe még ennél is alacsonyabb számban - kevesebb, mint 20\% - kerültek be. A legfelső pártvezetésnek a nők politikai tevékenységére vonatkozó attitüdjéről azonban az adatoknál sokkal többet árul el a nők kiválasztásának formális a módja. Sztahanovisták, nem tradicionális női munkát végzỏ ifjúmunkások, traktorosok képviselték a nőket a fontos párteseményeken, reprezentálva az új nőideálokat.

A nők politikai tevékenységet főleg az egyetlen női szervezetben, a Magyar Nők Demokratikus Szövetségében ${ }^{15}$ (továbbiakban MNDSZ) folytathattak, feladatuk ,a párt eszméit és akaratát átvigyék a lakosságnak a szervezet jellege szerint 'megcélzott' rétegére”, „transzmissziós” (Kornai 1993: 72) feladatot látva el a párt és a tömegek között. A feladatnak igazából azok a nők tudtak megfelelni, akik minden cselekedetüket a párt vezetőségének elvárásai szerint, gondolkodás nélkül végrehajtották. A nők akkori- és későbbi politikai és társadalmi szerepeinek a megitélése szempontjából nyernek ezek a jelenségek mélyebb értelmet. Mivel a nőszervezet funkcionáriusainak műveltsége az átlagnál is alacsonyabb volt, napjainkig továbbélő negatív attitűd alakult ki a politikai szerepet vállaló nőkkel szemben. Ugyanakkor a hatalmi hierarchia alacsonyabb szintjein tevékenykedő nők munkáját nemcsak a képzettség hiánya, hanem a férfiakból álló felső pártvezetés negatív attitűdjei is nehezítették. Ennek okai között egyaránt megtalálható volt a tradicionális női szerepeket hangoztató közvélekedés, valamint a funkcióba történỏ kiválasztás miatt kialakult ellenszenv.

\section{A nők társadalmi esélyegyenlőségét gátló tényezők}

A társadalmi újratermelési folyamatban való részvétel a nők számára akkor válhatott volna az esélyegyenlőség alapjává, ha a családi feladatokhoz kapcsolódó munkákat intézményesítik, valamint a gyermekek gondozásának-nevelésének a terhéből az állam jelentős részt vállal magára. Ehhez a gyermekellátó intézmények olyan volumenű emelésére lett volna szükség, amelyek mind a mennyiség, mind a nevelés minőségének tekintetében kielégítik a családok elvárásait. A pártvezetés viszont a nők egyenjogúságát, esélyegyenlőségét a magántulajdon intézményének felszámolásával, a nők társadalmi munkavégzésbe való folyamatos bekapcsolásával automatikusan megvalósulónak vélte és mint minden más területen, itt is a szovjet mintát másolta. ${ }^{16}$

A bölcsődei férőhelyek száma - a folyamatos növekedés ellenére - az ötvenes évek elején csak a 0-3 éves gyermekek 3,2\%-ának befogadására volt elegendő. A Központi Statisztikai Hivatal 1953. októberi (EÜ: 7/1953) jelentése szerint az adott korosztálynak csak 2,6 százaléka volt bölcsődés, miközben a gyermekes nők 38\%-a dolgozott (KSH 1958/II.: 765). A budapestiek ezen a téren előnyöket élveztek a vidéken élőkhöz viszonyítva, mivel a fővárosban a gyermekek $10 \%$-ának tudtak elhelyezést biztosítani.
Még lassabban növekedett az óvodai férőhelyek száma, annak ellenére, hogy ennek az intézménynek történeti hagyományai is voltak (Szalai 1986: 199-201). A magyar óvodapedagógiának már a két világháború között elkötelezett irányítói akadtak nálunk, munkájuk pozitívumai a későbbi időkben is meghatározták az óvodai munka alapelveit. A bölcsődei helyek számának relatív emelkedéséhez viszonyítva -, ami 1949-től négy-, négy és félszeres volt - az óvodában elhelyezhető gyermekek száma csak másfélszeresére nőtt, és egyedül 1951-ben haladta meg a háború előtti szintet. ${ }^{17}$ $\mathrm{Az}$ ide felvehető gyermekek alig érték el az adott korosztály egynegyedét annak ellenére, hogy a szakemberek többségének a véleménye szerint ebben az életkorban már pozitív hatása van a közösségben történő nevelésnek.

A gyermekellátó intézményeknek a szükségletnél kisebb mértékủ fejlesztése megduplázta a dolgozó nők terheit (KSH 1958: 765), mivel ilyen feltételek mellett nehéz volt a munkát és a családi kötelezettségeket egyszerre jól ellátni. Természetes, hogy az ezzel kapcsolatos problémák sem tartoztak a társadalmi diskurzus körébe, sőt, a propaganda a valósággal ellentétes jelenségeket mutatott be.

A családon belüli konfliktusok a nők egyre nagyobb arányú kereső tevékenysége, és a nőknek a háztartással és gyerekneveléssel kapcsolatos - jelentősen nem csökkenő - terhei között komoly feszültség volt. Ez több tekintetben kárára vált mind a családi, mind a munkahelyi feladatok teljesítésének. Lengyel László a női foglalkoztatottságot elemző tanulmányában a következő megállapításokat tette: ”...a nők ilyen nagyarányú bevonása az aktiv keresök közé bizonyos mértékig túlzott volt, nem egy vonatkozásban - elsösorban az ifjúság családi nevelését illetöen - kedvezötlen következményekkel járt. A nók munkába állásának folyamata túlságosan gyors volt, s így már eleve sem lehetett minden oldalról, sem gazdasági, sem társadalmi vonatkozásban kellöen megalapozott. A bölcsödék, a napközi otthonok, a közétkeztetés (...) szükségesnél lényegesen kisebb mértékü fejlesztése, a háztartások alacsony színvonalú gépesitése nem vette le a dolgozó nö válláról a háztartási és gyermeknevelési gondokat." (Lengyel 1958: 765).

Az 1945-ben kodifikált egyenlő munkavállalói jogok a megvalósulásukat segítő intézmények alacsony száma, vagy nem megfelelő funkcionálása miatt a társadalmi gyakorlatban nem érvényesülhettek. A házimunka és a keresőtevékenység összehangolását az is akadályozta, hogy a problémákat a nőknek egyedül kellett (volna) megoldaniuk, mivel a tradicionális férfiszerepek eközben alig változtak. A kettős teherviselés a női egyenlőség megvalósítását kizárólag a társadalmi munkamegosztásban való egyforma részvételre szűkítő ideológia szükségszerủ következménye volt. Az ellentmondásokat tovább mélyítette, hogy a növekvő női munkavállalás ellenére a legfelső pártvezetőség maga is bizonytalan volt, egyrészt az általa hirdetett „dolgozó nő” ideálját illetően, másrészt a megvalósítás folyamatának a tekintetében. „A munkához való jog és kötelesség szempontjából a társadalomvezetés a nöket mindvégig bizonyos értelemben kivételnek tekintette (...) a nök esetében a munkavállalás joga elvileg vagy a közfelfogásban sem vált soha kötelezettséggé," Ferge Zsuzsa (1982: 140) megállapításai az államszocialista társadalom egész időszakára érvényesek voltak. 


\section{Dolgozó nők - háziasszonyok}

A pártvezetés céljait a nők felé közvetítő nőszervezet, az MNDSZ agitációs tevékenysége egyrészt a munkahelyekre, másrészt a háziasszonyokra is kiterjedt. Ez utóbbi csoportnál kettős feladatot kellett ellátni, bevonni őket a munkába, illetve rávenni őket, hogy férjüket hatékonyabb munkára buzdítsák. ${ }^{18}$ Különös jelentősége volt ennek az agitációnak a bányászfeleségek között, akik a „bányászbecsület védelméért is harcoltak”, és mint az ország legmegbecsültebb dolgozóinak házastársai, segíteni kellett a férjeket abban, hogy méltóak legyenek a Párt, Rákosi bizalmára. A háziasszonyok tehát akkor válhattak a társadalom hasznos tagjaivá, ha házastársukat még több munkára, a tervek teljesítésére, túlteljesítésére ösztönözték.

A háziasszonyokat megcélzó propagandából kiolvasható, hogy az államszocializmus család- és nőképe jelentősen különbözött a tradicionális magyar társadalom családszerkezetétől, a férj-feleség mindennapokban megnyilvánuló kapcsolatrendszerétől. Éppen ezért a más értékrendszer alapján működő pártállamnak ahhoz, hogy hosszú távon hatékonyan funkcionálhasson, el kellett fogadtatnia új ideáljait. Az új értékrendszer kialakításának folyamata jól nyomon követhető a társadalom számára fontos ünnepek átalakítására irányuló törekvésekben.

\section{Nőnap - Anyák napja}

Az új nőideált a Nemzetközi Nőnap jelentőségének a hangsúlyozásával, ezzel párhuzamosan az előző időszak nőideálját szimbolizáló Anyák Napja leértékelődésével kívánták a társadalom felé közvetítetni. Míg a két világháború közti időszakban a nő legfontosabb hivatásának tartott feleség és anyaszerep jelentőségét az mutatta, hogy az Anyák Napja kötelező ünnep volt az iskolákban, addig az 1945 és 1955 közötti években a hivatalos ünneplést eltörölték. Intézményesítésére majd csak 1955. május 7-én került újra sor, ugyanakkor a nők legjelentősebb ünnepe továbbra is március 8 . maradt. Az ünnepség intézményesítésére azért volt szükség, mivel a tapasztalatok azt mutatták, hogy a „klérus igyekezett azt (mármint az anyák napját) a maga számára felhasználva" minden esztendőben megünnepelni, és ennek megakadályozása végett javasolták újra iskolai ünneppé nyilvánítását. (MOL 276. f. 89/358)

Az MDP KV Agitációs és Propaganda Osztálya a következő javaslatot készítette a Titkárság részére a Nemzetközi Nőnap megünneplésére „A Nemzetközi Nőnap előkészületeit fel kell használni arra, hogy fokozódjék a magyar nök aktivitása a gazdasági, politikai és kulturális élet minden területén, és ezáltal is növekedjék a nök társadalmi megbecsülése. "19 Természetes, hogy emellett még a Szovjetunió, a párt és az MNDSZ munkájának a népszerűsítése is szerepelt a feladatok között. Az ünnepség fényét az is erősíthette, hogy javasolták: a Párt KV írjon levelet a magyar nőkhöz, melyet a sajtó, rádió ismertessen, és az ünnepségeken olvassák is fel. Az ünnepség nem más, mint a nép tisztelete az öntudatos, dolgos, harcos asszonyok, édesanyák, feleségek és lányaik iránt. „A magyar nök ezután is mindenütt ott lesznek, ahol a béke nagy ügyéért cselekedni kell." Ez pedig, a dokumentumok szerint, nem lehetett más, mint a munka frontja és más társadalmi tevékenységek. A Nőnap méltó megünneplése nem történhetett volna másként, mint a nők tömeges teljesítmény-felajánlásával, a haza gazdasági erejének növelésére irányuló még fokozottabb munkálkodásával

A feleség/anya szerepkörről a társadalmi munkamegosztásban tevékenykedő nőre történő áttérés a „csak családjáért,, dolgozó nő presztízsének a leértékelődésével járt együtt. Ezt a tendenciát erősítette továbbá, hogy a nőnap átvette az anyai szerepkör funkcióját is. „Az édesanyák magasztos feladatukhoz méltóan teljesítsék családi és szülöi kötelességeiket, hogy gyermekeiket, dolgos, müvelt, hazájukat szeretö emberekké neveljék” (MOL 276. f. 89/163. ő. e. 409.) Az idézetből kiolvasható, hogy itt nem a családi intimitás megteremtése, hanem a társadalom nagy közösségéért végzett tevékenység vált az anyák alapvető feladatává.

1954-ben ugyan megrendezték az Anyák Megyei-, majd május 7-8-án az Anyák Országos Konferenciáját, az összejövetelek témája igen távol esett a világháború előtti anyák napi ünnepségekéitől, a tradicionális családokban betöltött anyai szerepkörtől, s helyette a szocialista közösségért dolgozó nő vált hangsúlyossá.

\section{Karácsony - Fenyőfa ünnep}

Egyes eseményekhez, személyekhez kapcsolódó ünnepek előtérbe kerülésének, vagy éppen eljelentéktelenítésüknek és megszüntetésüknek a konkrét tartalomtól elvonatkoztatott, tágabban vett ideológiai okai is voltak. Mivel „a karácsony 1945-óta harco jelentett a demokratikus erök és a klérus között", ennek az ünnepnek áttranszformálása „Fenyöfa ünneppé” egyidejüleg szolgálta az ünnep egyházi jellegének háttérbe szoritását, és a nök kivonását a klérus hatása alól" (MOL 276. f. 89/163. ö. e. 58.) A Vallás és Közoktatásügyi Minisztérium 1950. november 28-án megfogalmazott levele szerint az ünnep új jelentést kapott, amely nem volt más, mint a békeharcra és a nemzetközi szolidaritásra történő mozgósítás. A nőnevelők feladatává tették az akció politikai tartalmának állandó tudatosítását és ezzel a karácsonyi „elókészülésnek” az eddigitől eltérő módon való megszervezését. A szervezők még arra is vigyáztak, hogy ne legyen jelmezbál, mivel az esetleg az előző évek betlehemes játékaira emlékeztethetett volna. Az előkészületekre szánt rövid idő is azt a célt szolgálta, hogy a december 22-én, 23án és 24-én tartandó próbák megakadályozzák a gyermekeket, hogy felkereshessék a templomot, ezért a központilag előirt műsorokat csak december 19-én küldték ki a településekre. Ugyanilyen okokból tették kötelezővé a foglalkozásokon való részvételt 25-én és 26-án délelőtt a tanulók, délután pedig a szülők részére. 1952-ben, szovjet példa alapján, a karácsony másnapját törölték a hivatalos ünnepek sorából, helyette május 2-át fizetett munkaszüneti nappá nyilvánították. A karácsony, a családi körben eltöltött szeretet ünnepe egy napra szűkült le, és még ekkor is külön programokon kellett részt venniük a családtagoknak.

Tovább is sorolhatnánk az említett esetekhez hasonló példákat, amelyek az ötvenes években a megelőző társadalom jeles eseményeinek a megváltoztatására irá- 
nyultak. Azokban az esetekben, amikor az ünnepet névlegesen megtartották, a politika jóvoltából mégis elvesztette eredeti jelentését s új tartalommal telítődött.

Természetes, hogy az áttranszformált ünnepek a közvetlen változások (munka-, munkaszüneti nap) mellett legfeljebb hosszabb távon fejthették volna ki a hatásukat, ezért azonnali új példaképekre is szükség volt. Ezek az új ideálok nem is lehettek mások, mint a „,ép álmait valóra váltó...” apák, akik a párt által vezetett közösségben - amivé a kommunista vezetők a hagyományos családot kívánták átalakítani - legalább olyan kitüntetett szerepet játszottak, mint a marxizmus alapítói által elítélt patriarchális családapák. A korabeli dokumentumok szerint a karizmatikus vezérek nemegyszer mint új istenek tủntek fel. Így nem csodálkozhatunk azon, hogy a hetvenéves zempléni Szabó Béláné a következőkkel magyarázta, hogy miért festette ki a házát Sztálin 70. születésnapjának a tiszteletére. „Máskor karácsonyra szoktam, de Sztálin elvtárs a mi megváltónk és az ő tiszteletére teszem. (Pünkösti 1996: 255.) Rákosi Mátyás a minisztertanács elnökévé történt megválasztása alkalmából kapott hasonló tartalmú levelet.

\section{Összefoglalás}

Az ötvenes évek politikai, gazdasági változásait a nők szempontjából elemezve megállapítható, hogy ebben az időszakban a társadalmi - leginkább a munkavállaláshoz kapcsolódó - szerepek váltak igazán hangsúlyossá, és ezzel párhuzamosan a tradicionális női-, családi szerepek leértékelődtek. A magánélet éppen úgy elhanyagolt területe volt e korszaknak, mint a tradicionális értékek mentén szerveződő család és a hagyományos értelemben felfogott nőiesség. A nemek közötti egyenlőség/egyformaság szélsőséges formáját példázta Gergely Miklósnak a Ludas Matyi 1952. október 22-i számában megjelent karcolatában vissza-visszatérő refrén: „itt nincs nö, és nincs férfi, csak kollégák vannak."

Ugyanakkor a változások annak lehetőségét is megteremtették, hogy a nemek társadalmi és családi viszonyaiban végleg eltűnjenek a férfi - férji autoritás alapjai, és a jogegyenlőség deklarálása hozzájárult ahhoz, hogy felgyorsuljanak mindazon folyamatok, amelyek a magyar társadalom tradicionális érték és normarendszere miatt a megelőző időszakban meggátolták a nőket abban, hogy életlehetőségeik terén közelítsenek a férfiakhoz. Természetes, hogy ezek a változások csak a valóságot elleplezzỏ propaganda szintjén látszottak problémamentesnek, a valóságban tele voltak megannyi ellentmondással. Pozitívumként értékelhető, hogy először ekkor módosultak - legmagasabb állami-, politikai szinten - a nők munkavégzésére vonatkozó évszázados törvények, szokások és elvárások; negatîvumként értékelhető viszont, hogy az átalakulással szemben kritikákat megfogalmazókat elhallgattatták, az ellentétes szerepelvárások miatt kialakuló nehézségekről, konfliktusokról pedig nem lehetett nyíltan beszélni.

Ebből következik, hogy az ötvenes évek politikai, gazdasági és társadalmi változásai hatására a nők társadalmi- és családi szerepeit ellentmondások jellemezték, ugyanakkor ezek a „női problémák” érdekérvényesítés hiányában láthatatlanok maradtak. A Rákosi diktatúrában a nők társadalmi egyenlőségét hirdető jelszavak ellenére, a nők érdekei, mint minden partikulárisnak tartott érdek feláldozható, vagy alárendelhető volt az általános célnak. A bekövetkezett változások ellenére a nők alárendelódésének intézményes okai, mind társadalmi, mind a magánélet színterein továbbra is fennmaradtak. Ezért társadalmi helyzetükben, a másik nemhez való viszonyukban csak olyan változások következhettek be, amelyek a szovjet típusú államszocializmus fennmaradását segítették elő.

\section{Jegyzetek}

Uj Magyar Képzőművészet. 1950. 4. Révai József megnyitó beszéde az 1950-ben rendezett első Magya Képzőmüvészeti Kiállításon. (Kiemelés tỏlem S. M.)

A nők oroszországi, majd szovjetunióbeli történeténél célszerủ a helyzetüket meghatározó változásokat a bolsevik párt, föleg a pártpolitikát kijelölö személyiségek véleményén keresztül elemezni. Mivel az adott szisztémában minden a

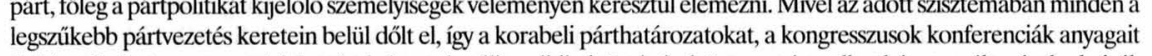
és jelentéseit elemeztem. A jelentések és az aktuális politikai történések összevetése adhat képet a változások okairól. Forrás az Oroszorzzágra és Szovjetunióra vonatkozó XX. századi képes történeti kronológia, valamint az 1996-ban Forrás az Oroszorszagra és Szovjetunióra vonatkozó XX. századi képes törteneti kronologia, valamint az 1996-ba
megielent „A Szovjetunió torrtenete” címú munka. megjelent „A Szovjetunio története" címú munka.

Marx és Engels a nemek kôzotti egyenlôtlenség eredetét a társadalmi egyenlőtlenségek eredetére, az osztálykülönbségekre vezetik vissza, amely kialakulásában, megszilárdulásában és tartós megmaradásában a munkamegosztásnak, a magántulajdonnak és a házasság intézményének tulajdonítottak jelentős szerepet. „A munka megosztásával... amely a munkának a családban való természetadta megosztásán és a társadalomnak egyes egymással való természetadta megosztásán és a társadalomnak egyes egymással ellentett családokra való szétválásán nyugszik, egyidejüleg az elosztás is adva van, mégpedig a munkának és termékeinek mind mennyiségre, mind minőségre egyenlötlen elosztása, tehát a tulajdon, amelynek a családban, ahol a nő és a gyermekek a férfi rabszolgái, megvan már a csirája, az első formája. A családban levő, persze még nagyon kezdetleges, látens rabszolgaság az első̉ tulajdon, amely egyébként itt már tökéletesen megfelel a modern közgazdászok definíciójának, amely szerint a tulajdon idegen munkaerô feletti rendelkezés.” Marx 1844-ben irt, „A szent család vagy a kritika kritikája” címü munkájából idézett gondolat lényege, hogy a férfi és nő viszonyának alakulását az általános emberi fejlódés fokméröjeként tekintette. A tanulmányban elốrevetítődik az a későbbi, a marxizmus gyakorlatában megjelenő megközelítési mód, amely a nők problémáit nem nőkérdésnek, hanem egy általános társadalmi egyenlőség megvalósitásának részeként tünteti fel. Marxnál az osztálykülönbség megszünése, amelynek alapja mindennemü magántulajdon megszünése, együtt jár a magántulajdon újratermelését biztosító polgári család intézményrendszerének eltủnésével, amely megszabadítja a nỏt a házasság általi elnyomás lehetőségétôl, megteremtve a nő bekapcsolását az általános emberi fejlődési vonulatába. Gyáni szerint (1995) amíg 1920-ban a városi bérmunkásoknak csak a fele dolgozott ipari proletárként, addig a világháborút megelőző időkben már közel kétharmaduk állt ipari munkásból.

Az 1945. november 4.-én tartott nemzetgyülési választásokon, a nemzetgyülés 420 tagja közül 14 a nơi képviselö, az 1947 augusztusi választásokon is jelentős eröfeszítések történtek a női szavazók megnyerésére (Tóth M. 1975: 9-10)

Ramirez, F. O. - Y. Soysal - S. Shanahan (1997) A nők választójogának alakulásával foglalkozó kutatások szerint az általános választójog kibővítése, amely 1945-től Magyarországon is tapasztalható, nem a szocialista országok sajátossága, hanem a modernizációs törekvések velejárója. A modernizálódó országok lakossága, társadalmi berendezkedéstől függetlenül, részesülhetett a politikai jogok általános kiterjesztésében sága, társadalmi berendezkedéston Ezzel a ténnyel magyarázható, hogy Magyarország Guatemalával, Indonéziaval, Japannal es Olaszorszaggal
egy időben kodifikálta az általános választójogot, míg Svájc csak 1971-ben tette ezt. Marx: A szent család vagy a kritika kritikája (1844.)In: MEM 2. kötet 194-195. o. Fontos megkülönböztetni a marxizmus klasszikusainak munkáit a marxizmustól, vagy marxizmus-leninizmustól. A nőkérdésben is alapvető különbségeket találunk a klasszikusok elmélete és az elméletre hivatkozó, de azzal sokszor ellentétes gyakorlatot különbségeket talâlunk a klasszikusokętós

A nők számarányának folyamatos növekedése figyelhetỏ meg az utolsó, alternatívákat nem tartalmazó vá-

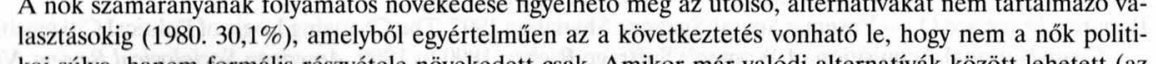

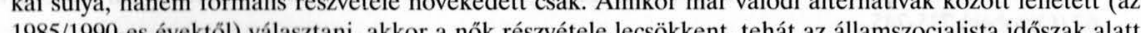
nem változott meg a nói politikusokkal szembeni tradicionális/elóítéletes attitüd. 
(MOL 276. f. 54/217. 6. e. 9.) A személyigazolvány bevezetését nem is ebbỏi a célbôl határozták el. ......pontosabbá tenné a lakosságról vezetett nyilvántartást, elösegitené a munkaerö vándorlás csökkenuésá, meghönnyitené a AVH és a Rendôrség munkáját az imperialista ügynökök és oszzályellenség, politikai és gazdasági bünözök ellen

Ez a folyamat az 1957. évi V. törvénnyel teljesedett be. Ekkortól vesztette érvényét az a korábbi joggyakorlat, amely szerint a nỏ automatikusan megkapta a férj állampolgárságát, és az nem a saját választásától függött.

1 H. Sas Judit idézi Vadász Lajos: Tételes magánjogunk. címmel 1942-ben megjelent munkájából. (H. Sas 1984: 77).

12 (Balogh 1986: 433). Az új családjogi törvény elemzésénél a továbbiakban ebből idézünk (Kiemelés tőlem S. M.) 3 „A jogalkotó elvetette tehát a régi HT vétkességi rendszerét a bontás tekintetében, és a házasság feldúltságának a kritériumár fogadta el a bontás alaptényállásául.” (Csiky 1990: 122).

4 KSH 1960/3.

A Magyar Nők Demokratikus Szövetsége elnevezést 1944. decemberétől (Orosháza) használta az 1944. november elején Szegeden megalakult Antifasiszta Dolgozó Nők Szövetsége. 1945, janúr 28-án Debrecenben az országos szervezet, február 18.-án Budapesten az Országos Vezetőség alakult meg. Az MKP a kommunista nők aktív szervezỏmunkáján keresztül érvényesítette akaratát.

16 Az 1917-1926 közötti családjogi vitákban és a XII. pártkongresszuson Alexandra Kollontaj nézetei veresé-

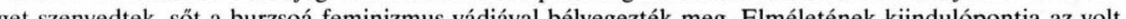
get szen de hogy a nek kozbli gygnôtlo alávetere kak diferenciab́l

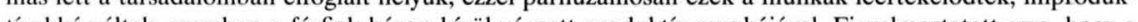
trakká valak, szo

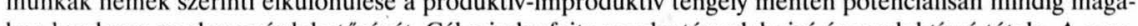
ban hordozza az elnyomás lehetosegét. Cel mindenfajta munka tarsadalmivá es produktivaá tétele. A megvalósitas közétkeztetés altalânossá valâsát (Kollontaj 1921: 259). 1923 aprilis 13-ân egy eróteljes kritikát fogalmazott meg a Pravdában a kormány - pénzügyi nehézségekre hivatkozó - halogató politikájával kapcsolatban, mely akadályozta ezeknek az otthonoknak es a nôk munkajat megkonnyito kozétkezdéknek a létrehozását.

A kevés férőhely a háborús károknak is köszönhető, amelynek következtében az óvodák száma 1140-röl 1945-re 992-re csökkent, a gyermekszám pedig 112 ezerről, 52 ezerre.

A házi agitáció a szociáldemokrata párt szervezési gyakorlatából került át az MNDSZ feladatai közé, de míg az előbbinél „Jelentösége kettős: a pártaktiva munkába vonása és az inaktiv párttagokkal való kapcsolat felvétele és fenntartása" (Titkári... 1946. 6.) volt, addig az ötvenes években a pártpolitika érvényesítésének egyik harcos eszközeként szerepelt.

19 MOL 276. f. 89/273. ő. e. 404-409. (Kiemelések tőlem S. M.)

\section{Felhasznált irodalom}

Andorka Rudolf 1982. A társadalmi mobilitás változásai Magyarországon. Bp., Gondolat.

Balogh Sándor (szerk.) 1986. Nehéz esztendök krónikája 1949-1953. Dokumentumok Bp. Gondolat.

Csiky Ottó 1990. A házasság felbontása. Bp., Közgazdasági és Jogi.

Ferge Zsuzsa 1982. Társadalmi újratermelés és társadalompolitika. Bp., Közgazdasági és Jogi.

Gyáni Gábor 1995. A városi munkásság szerkezete Magyarországon1910-1941 között. In: Valuch Tibor (szerk.) Hatalom és társadalom a XX. századi Magyar történelemben. Bp. Osiris, 553-557.

Gyarmati György 1996. Március hatalma a hatalom márciusa. Bp., Paginarium.

H. Sas Judit 1984. Nöies nök és férfias férfiak. Bp., Akadémiai.

Halász József-Kovács István-Szabó Imre (szerk.) 1965. Az állampolgárok jogai és kötelezettségei. Bp., Akadémiai. Kornai János 1993. A szocialista rendszer. Bp., HVG

Kelly-Gadol, Joan 1993. A nemek társadalmi viszonyai. Aetas, 4. sz. 139-153.

Lengyel László 1958. A foglalkoztatottság alakulása. In: Statisztikai Szemle XXXVI. Évf. 1958/ II. Félév. KSH $762-772$.

Marx, Karl 1977. A szent család vagy a kritika kritikája (1844.) In: MEM 2. kötet Bp., Kossuth.

Pünkösti Árpád 1996. Rákosi a Csúcson 1948-1953. Bp., Európa.

Rákosi Mátýás 1951. A békéért a szocializmus épitéséért. Bp., Szikra.

Rákosi Mátyás 1997. Visszaemlékezések 1940-1956 1-2. Bp., Napvilág.

Ramirez, Francisco O - Y asemin Soysal-Suzanne Shanahan 1997. The Changing Logic of Political Citizenship: Cross-National Acquisition of Women's Suffrage Rights, 1890 to 1990. American Sociological Review, Vol. 62 (October) 735-745.

Szalai Júlia 1986. Az egészségügy betegségei. Bp., Közgazdasági és Jogi.

Szalai Júlia 1986. Az egészségügy betegségei. Bp., Közgazdasági és Jo
Tóth Matild 1975. A magyar nök jogainak fejlódése. Bp., Táncsics.

Varga György 1998. Adalékok és szempontok a Magyar Dolgozók Pártja hatalmi helyzetćhez. Mültunk, 2.

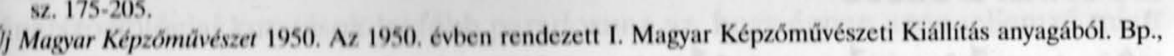
Athenaeum

Vida Sándor (szerk.) 1985. Pärtkongresszusok és pártpreferenciäk 1918-1980. Bp., Kossuth.

KSH 1977. Adatgyüjtemény a keresơ nökröl. Bp., KSH november 14.

KSH 1960. A nök helyzete régen és most (Foglalkozási, bérezési, műveltségi és szociális viszonyok) Statisztikai Idôszaki Közlemenyek 32. kotet Bp., KSH 3. sz.

munkasok, alkalmazottak és kisipari szovelkezeti tagok száma nem és kor szerint 1949-1958. Bp., KSH 